\title{
INFLECTION OF STUDENTS' VOCABULARY MASTERY ON MULTIPLE CHOICE TEST STUDENTS' AT VOCATIONAL HIGH SCHOOL IN BOGOR
}

\author{
Yani Octafia \\ Pamulang University \\ English Letters Departement \\ Email: dosen01153@unpam.ac.id
}

\begin{abstract}
This research aims to determine and analyze the inflection of vocabulary mastery on students' vocational high school in Bogor. The population observed in this study was eleventh grade students of vocational schools in Bogor. In the academic year 2019/2020. The respondents in this study were students at one of the vocational schools in Bogor. This research method uses a qualitative descriptive method, the population in this study were students of class XI Sirajul Falah Vocational School in Bogor totaling 336 students. The sampling technique in this study uses a probability sampling technique. From this population $20 \%$ of the population was taken so that the total sample was 68 students. The instrument of this research is multiple choice test. Researchers ask students to answer multiple choice test on vocabulary instrument. Indicators used to determine vocabulary mastery, namely: 1) determining words that have collected meanings / synonyms, and 2) determining words that have contradictory meanings / antonyms. 3) determining words related to the spelling 4) determining the words related to grammar. This research was carried out using tests given directly to the subjects studied in the vocabulary mastery aspect given 20 questions in the form of multiple choice. Based on the data analysis, there are 68 respondents who were given 20 multiple choice questions with 4 indicators, namely the correct answer indicator and the rest are the number of respondents' wrong answers. Based on the data analysis shows that there are $84 \%$ of questions related to true and the remaining $16 \%$ of questions cannot be answered correctly by students. So it can be concluded that there is inflection vocabulary mastery on vocabulary test.
\end{abstract}

Kata kunci: Vocabulary Mastery; Multiple Choice Test

\section{INTRODUCTION}

As we know humans need language as a communication. Language as a communication tool between a person to each other, it has a very important role in human life because with language, humans can interact about anything. Based on the way the language is presented and given, it is divided into two means, namely written and spoken language.

In learning English, there are many skills that we must master and we must be able, namely writing, listening, reading, and speaking. We will meet with two important components that support the skills namely grammar and vocabulary. They are very important to learn and master in English. 
In learning English, we will be introduced to vocabulary. There are many reasons why vocabulary is introduced and taught previously, because vocabulary is easy to understand by children, it causes there are no rules or formulas that children need to know such as when learning grammar and because vocabulary is a supporter of grammar and skills.

When we listen to something in English with vocabulary that we master, we can easily get the meaning of what we hear, with speaking, when we will convey an idea then we need a collection of vocabulary that we can make to convey it, we can use the vocabulary in sometime because we have ever heard it and it is saved on our mind. Most people when visiting a dictionary to help them communicate with others compared to grammar books. It means that the amount of vocabulary we have can help us communicate with other people.

In the end with the mastery of vocabulary, children can master English exactly and easily. In writing, children must think of a collection of vocabulary what they should put in the ideas they have. In mastering vocabulary, we will more easily use the structure or grammar. The more vocabulary we know and we have, so we will make it easier for us to write the writings of others. Difficulties mastering vocabulary experienced by many students, therefore, the authors conducted research into a school by providing a test in the form of multiple choice tests and descriptive writing essay tests to find out how much influence their vocabulary has.

\section{A. Vocabulary Mastery}

In learning activities or in examinations and exercises, difficulties experienced by students are only related to the mastery of vocabulary, much or at least the vocabulary owned by students affects the ability and content or quality of the writing. According to Soedjito and Djoko Saryono (2011: 3), providing a definition that "vocabulary is wealth of words owned by a language". From his statement Vocabulary is precious something that can distinguish human with tea other in wring and speaking activity, or is part of language activity. The wealth of a person's vocabulary is considered of someone's intelligence or education. So, can be understood that the quality and quantity vocabulary or vocabulary owned by students will help students in get various information conveyed by the teachers, lecturers or information from various other learning resources. Vocabulary mastery both inflect students' skill to communicate, to write, both speaking and writing. Tarigan (2015: 2) explains that the quality of language skills a person depends on the quantity and quality of the vocabulary he has. The richer the vocabulary is, the greater our possibilities skilled in language. This means that 
someone's mastery of vocabulary candetermine the quality of the person's language. Without having mastery vocabulary is very difficult for the person to hold good communication and interaction. According to Nurgiyantoro (2014: 338) mastery of vocabulary can be divided into mastery that is receptive and productive, i.e. the ability to understand and use vocabulary.

From some of the above understanding can be concluded that vocabulary is one element of language, and there is no language without words and vocabulary. The word is a symbols to expressan idea and an imagination. These words are tools used to exchange ideas. The more words used by a human the more ideas, so that he is able to convey his ideas effectively. Related to this, vocabulary is the most important element students must have in achieving the all of language skills. In other words, it can be said that vocabulary is one of the important language components in writing.

So, it can be concluded that students who have vocabulary mastery then he will be able to write essays or paragraph in any form with writing that is easily understood and enjoyed by readers.

\section{B. State of Art}

Munirah (2016) conducted a research entitled "The Effect of Vocabulary Ability and Sentence Structure on the Ability to Write Paragraph Descriptions in High School Students" she does this study to determine the effect of the ability to use vocabulary and sentence structure on the ability to write a description essay, the data obtained were analyzed using multiple linear regression analysis. This type of research is correlation research or research that wants to find out the influence of three variables.

The next research was done by Agnita W., Danny. 2015. “The Effect of Vocabulary Mastery on Writing Skills on Japanese Language Education Students in Semester III Semarang State University" She stated in his research that in the process of writing, mastery of vocabulary is very necessary in writing so that students can convey information well and there is no longer asynchronous between paragraphs, repetition of sentences and so on. The data collection method used in this study is the documentation method used to find out data on NIMs and the number of students and the test method used to obtain data on the value of vocabulary mastery and translational skills.

The last research was conducted by Sri Mulyati (2015) "The Influence of Vocabulary Mastery, Grammatical Mastery and Emotional Intelligence on German Writing Skills for 
Students of Class Xi High School 1 Imogiri Bantul" in his research, he argues that in language learning, writing activities are very important to be mastered by students. Writing skills are also one of the productive language skills that students must master in perfecting their language skills. Meanwhile, basically there are still many students who have difficulty in mastering writing skills.

\section{Conceptual Framework}

In this research, there is problem that we want to solve; mastery of vocabulary owned by students. Students can answer several questions related to synonym, antonym, spelling and grammar.

\section{RESEARCH METHODOLOGY}

\section{A. Type of Research}

The approach taken by this research is a qualitative approach. According to Sugiyono (2016: 7) Qualitative research method is called as a new method, because of its popularity not long ago, planted post positivistic because it is based on the philosophy of post positivism. This type of research is a case study, because this study uses a qualitative approach and includes case study research, the results of this research are descriptive-analysis in the form of written or oral words of observed behavior, especially related to how vocabulary mastery inflected students' ability in writing descriptive.

\section{B. Location, Population and Sample of Research}

The research location is the place where the research will be conducted, to obtain data or information relating to the problem or research focus. The place or region that will be used as the location in this study is Sirajul Falah Vocational School located in Parung Bogor, thus the researcher considers this location to be very affordable by researchers. This research schedule is for the $2019 / 2020$ school year.

Spradley (Sugiyono, 2016: 297) said that Social situation or social situation consists of three elements, namely: place, actors, and activities interacting synergistically. The population or data source in this study were all students of class XI Vocational School Sirajul Falah Parung Bogor with a total of 336 students.

According to Sugiyono (2016: 122) states that there are two sampling techniques, namely Probability Sampling and Non Probability Sampling. In this study, researchers used 
one technique from Probability Sampling, namely simple random sampling technique. Simple random sampling technique is a technique that takes individuals for samples from the population in a random or random way, because the population from which the sample is taken is a homogeneous population containing only one characteristic, so the desired sample can be taken arbitrarily or randomly. Therefore, this study took 68 samples from all of the students in class XI.

\section{Data Instrument}

The assessment of vocabulary mastery and writing skills in this study uses test techniques. The form of tests used in this study are vocabulary mastery tests and descriptive writing skills tests. The test used to measure the level of vocabulary mastery is in the form of multiple choice tests for 20 questions that contain synonyms, antonyms, spelling and grammar.

\section{Data Collection Technique}

Data collection techniques can be done through settings from various sources, and various ways. The data collection techniques used in this study include observation techniques and documentation techniques. Data Collection Techniques. The data collection techniques used in this study consisted of vocabulary mastery test data values are based on true and false criteria of mastery of the vocabulary tested.

\section{E. Data Analysis}

Data analysis is the process of organizing and sorting data into basic patterns, categories, and description units so that themes can be found and work hypotheses can be formulated as suggested by the data. Data management or data analysis is an important stage in such a way as to successfully conclude the truths desired in research. In analyzing this data, the writer uses descriptive qualitative analysis techniques, where the writer uses this technique to describe, tell, describe and describe qualitative data that the author has obtained from the results of data collection methods.

\section{RESEARCH FINDINGS}

In this chapter the results of the research and analysis of the data will be explained described based on problems and research objectives that have been explained previously. 


\section{Data description of Students' Vocabulary Mastery}

In the learning process the steps taken are to explain what it is about vocabulary, and some indicators that also contain the test what are synonyms, what are antonyms, about spelling in English words, about word structure or grammar. then researchers gave 20 questions in the form of multiple choice tests. Then the researcher calculates the total achievements of the 4 indicators including the total wrong answers made by students.

Table 1 Data Description Students' Vocabulary Table

\begin{tabular}{lll}
\hline $\begin{array}{c}\text { Vocabulary Mastery } \\
\text { Indicators }\end{array}$ & $\begin{array}{c}\text { Frequency } \\
\text { (sentences) }\end{array}$ & Percentage \\
\hline Synonym & 289 & $21 \%$ \\
\hline Antonym & 276 & $20 \%$ \\
\hline Spelling & 293 & $22 \%$ \\
\hline Grammar & 287 & $21 \%$ \\
\hline Wrong answer & 215 & $16 \%$ \\
\hline Total & $\mathbf{1 3 6 0}$ & $\mathbf{1 0 0 \%}$ \\
\hline
\end{tabular}

Based on data from the table above, it shows that the correct number of answers from all indicators is 1145 questions out of 1360 remaining questions are 215 incorrect answers, for those 68 respondents each gets 20 multiple choices. Namely delivery of questions relating to synonyms of 289 , questions related to antonym as much as 276 , questions related to spelling as many as 293 , questions related to grammar as many as 287 and the remaining number of incorrect answers as many as 215 questions. From this description it shows that the student vocabulary ismore adequate in the material related to spelling and the number of antonym questions is the lowest mastered material of all students.Judging from the percentage, however it is seen from this table that there is a level of mastery of vocabulary in students. These include $21 \%$ synonym-related questions, $20 \%$ antonym-related questions, $22 \%$ spelling-related questions, $22 \%$ grammar-related questions $20 \%$ and the remaining $16 \%$ wrong answers.

From all of these descriptions it can be concluded that the level of vocabulary mastered by students is very adequate, this is evident from the number of questions and the percentage that the correct answers are far higher than the wrong answers, there is a mastery of vocabulary mastery of the questions about the indicator questions.

\section{CONCLUSIONS AND SUGGESTIONS}


Based on the results of the research described in chapter IV, it can beconcluded that there is an influence of mastery of vocabulary on the ability to multiple choice test of students, class XI of Vocational School Sirajul Falah Parung Bogor in 2019/2020 school year.This is evident from the total indicators of the questions given to students, they were able to answer the test with a higher number of scores than incorrect answers. It is $84 \%$ they get good answers, and only $16 \%$ get wrong answers.

Based on the discussion of research, in increasing masteryEnglish vocabulary of students, the authors convey the following suggestions:

\section{a. For students}

In studying the mastery of language vocabulary, it is expected to frequently read words related to synonyms, antonyms and so on so students can distinguish many kinds of words. Students can understand and identify words spelling, which is which letters are not read or are silent in reading an English word, and students can use grammar or grammar appropriately and they can choose the right answer in the choice of answers provided

\section{b. For teachers}

With a variety of tests that have been tested, it can become one of the teaching alternatives given to students' in improve vocabulary mastery.

\section{c. For further researchers}

In language learning, it is not only done in methods multiple choice tests only but there are various ways and methods of teaching, in order to improve mastery of student vocabulary. Expected through this test can improve and develop more interesting methods student attention, as well as a material consideration for researchers next.

\section{BIBLIOGRAPHY}

Kusnadi, M., \& Hardian. (2016). Pengaruh Kemampuan Kosakata dan Struktur Kalimat terhadap Kemampuan Menulis Paragraf Deskripsi Siswa SMA. Jurnal Pendidikan Bahasa dan Sastra, 16(1), 78-87. https://doi.org/10.17509/bs_jpbsp.v16i1.3064

Mulyati, S., \& Sahayu, W. (2015). Inflection Vocabulary Mastery, Structure Mastery and Emotional Intelligence on German Writing Skills for Students' Class XI High School 1 Imogiri Bantul. Journal Theodisca Lingua, 4(5), 1-11. https://doi.org/10.21831/10.21831/TLv1i1

Nurgiyantoro, B. (2014). Penilaian Pembelajaran Bahasa Berbasis Kompetensi. Yogyakarta: BPFE.

Soedjito. (2009). Kosakata Bahasa Indonesia. Jakarta: Gramedia Pustaka Utama. 
Yani Octafia

Vol 5 No 1

ISSN : 2541-6995

E ISSN : 2580-5517

Soedjito, \& Saryono, D. (2011). Kosakata Bahasa Indonesia. Malang: Aditya Media Publishing.

Sugiyono. (2016). Metode Penelitian Kombinasi (Mixed Methods). (M. Sutopo, Ed.) Bandung: CV. Alfabeta.

Tarigan, H. G. (2015). Pengajaran Kosakata. Bandung: Angkasa.

W., A., \& Danny. (2015). The Effect of Vocabulary Mastery on Writing Skills on Japannese Language Education students in Semester III State University. Semarang: Universitas Negeri Semarang. 